\title{
Students' Perceptions of the Use of Instagram Social Media as One of Generation Z's Political Education Facilities
}

\author{
Radifa Hudia ${ }^{1, *}$, Idrus Affandi ${ }^{2}$ \\ ${ }^{1,2}$ Universitas Pendidikan Indonesia, Bandung, Indonesia \\ *Corresponding author. Email: radifahudia@upi.edu
}

\begin{abstract}
Based on the mandate of the law, women can be active in politics at least 30\%. However, in fact, since 1955-2014, the 30 percent female participation rate has not even been fulfilled. Therefore, it is important to find a breakthrough for political education. And one of them uses social media Instagram as the most popular social media by generation $z$ today. Where at this time social media (Instagram) has become an inseparable part of everyday life, both children, parents, and almost all levels of society use social media (Instagram) especially among male students, especially for college students. woman. And social media can be used as a means of political education for generation $z$ to know about political insights indirectly. Therefore, this study aims to describe the views of female students on the use of social media (Instagram) as a means of political education for generation $\mathrm{z}$. The method used is an approach using the phenomenological method. And the phenomenological method is a method that examines the awareness of the main perspective of a person. And the results of the study show that the use of social media Instagram as a means of political education can actually provide a new perception of politics and build women's political awareness. Another discussion was about that social media greatly contributes to increasing literacy, but political parties have not been able to optimize it in playing their role as one of the institutions mandated by law to conduct political education. The conclusion is that the use of Instagram social media can increase literacy and political awareness for generation $\mathrm{Z}$, especially for students about good politics.
\end{abstract}

Keywords: Political Education, Social Media, Student.

\section{INTRODUCTION}

The development of advanced and modern civilizations requires time, energy, money, and hard work by every component of society in all areas of life. This development is certainly carried out by every citizen, regardless of gender, both male and female. In Indonesia, people, in general, tend to view men as more important to carry out these tasks. This is as stated by Wahyuningroem et al (2011) stating that in Indonesian society the problem that always exists in society is the problem of the poor balance or equality of political roles between men and women in politics in Indonesia (page: 95) [1]. However, it should also be remembered that the participation of women in the life of the state is also an important element in building an advanced nation's civilization. Women themselves have a role and have complex, sensitive, and weak problems in terms of physical endurance, therefore it will be difficult for men to understand, especially in making decisions or policies that are in accordance with the needs of women. In other words, women are specific in terms of getting protection and comfort, as well as security when they are outside the home. The law was enacted to help women feel protected when outside to earn a living at night. In the future, it is hoped that the involvement of women in politics will be very important in channeling the needs and protections of women outside the home. Of course, through the making of regulations or laws initiated by women themselves. The same view was also expressed by Budiatri, P (2011), revealing that the participation or participation of women in government is to represent the interests and needs of women and must be able to be carried out and realized properly (page: 99) [2]. However, the fact is that the level of participation of citizens, especially millennial voters or (students and students) in general elections is still low. Meanwhile, 
the issue of women's political representation rights in Indonesian politics is regulated in Law Number 7 of 2017 [3]. Where the law, regulates the minimum limit of 30 percent of women's representation in the implementation of general elections.

The facts are that the involvement or participation of women in politics is still low and has not met the

\section{WOMEN'S \\ REPRESENTATION IN DPR- RI FROM 1950-2014 PERIOD}

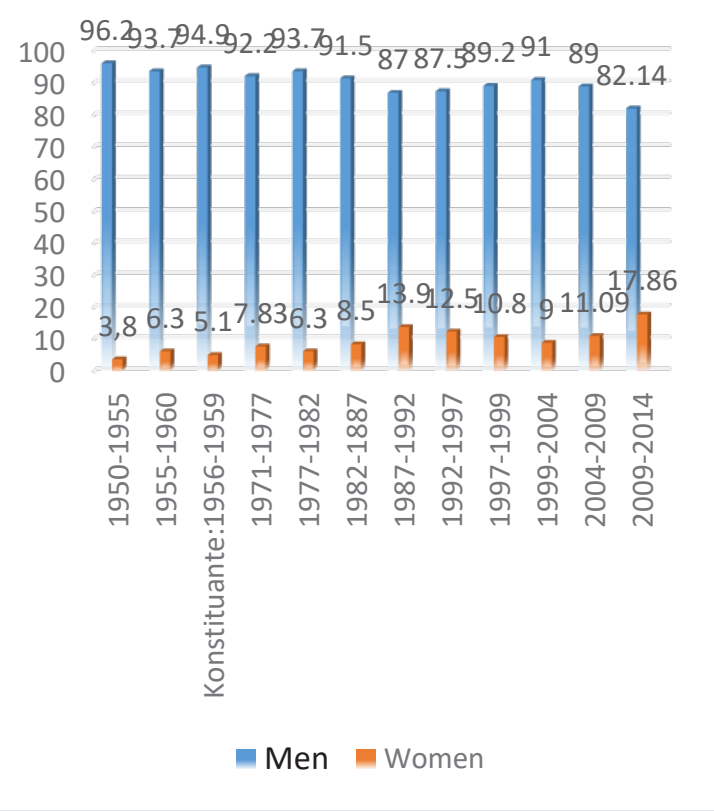

Figure 1. Women's Representation In DPR-RI From 1950-2014 Period.

From figure 1 above we see that the fact that a low level of representation of women than men in terms of participation of each gender in taking part in politics in Indonesia. Where we can see that from 1950 to 2014 women have never been able to fulfill the 30 percent quota for women's participation in parliament as mandated by law. While the quota for male representatives, despite a decrease in the percentage of their representation in parliament, always occupies a fairly high representative city, namely, from 92.2 percent to a decline of around 82.14 percent. From these data, we can see that the participation of women in parliament since the 1950 s has indeed had fairly low participation compared to men and this event has been happening for a long time and is still happening in people's lives today, especially for some people who still adhere to the feudal system.

The next data is about women's representation in the ASEAN region or Southeast Asian countries which shows information about the low level of women's participation in parliament in Indonesia, namely 19.8 percent when compared to neighboring countries such as the Philippines, which has a relatively high index of 29.5 percent. and Singapore,
$30 \%$ quota as provided by the constitution. This can be seen from the data on the level of women's participation in parliament and the fact society until now. This is evidenced by Kurniawan, M (2014:719) who provides information regarding the representation of women's political participation from 1950-2014 [ 4 ] as follows:

where the index of women's representation inparliament is quite high at 23.8 percent. And we can see from the graphic image below, namely:

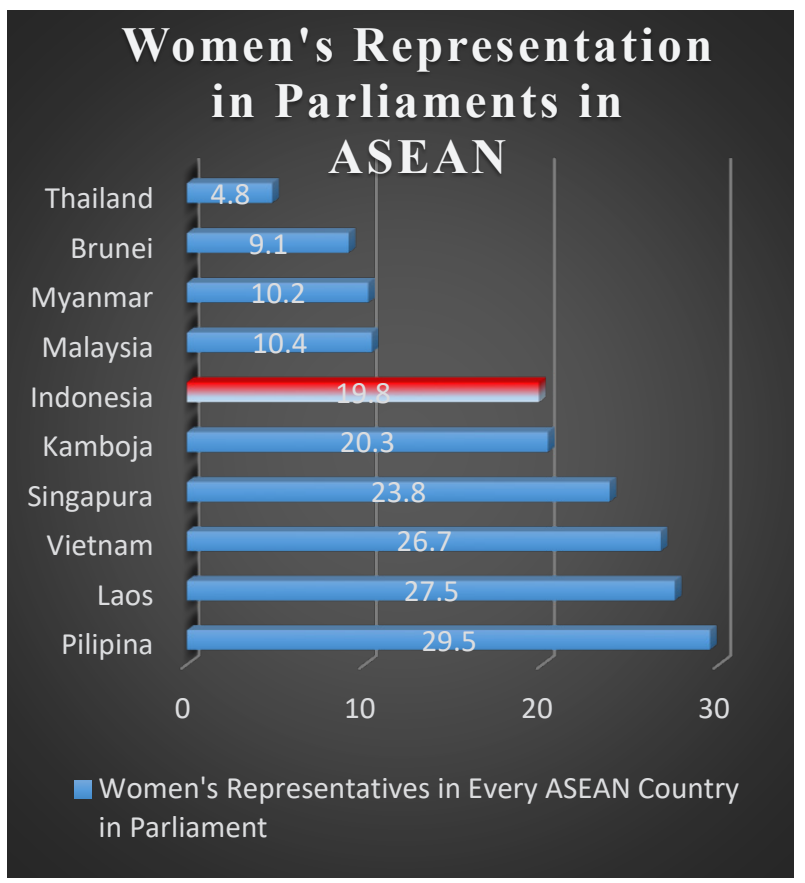

Figure 2. Women's Representation in Parliaments

$$
\text { In ASEAN. }
$$

Therefore, it is important to promote the representation of women in politics, both in terms of quality and capacity. As well, look at the legal basis of the Indonesian state, the Constitution of the Republic of Indonesia Year 1945 article 1, paragraph 2 implies about the real power will always be people's hands and implementation was carried out by the 1945 Constitution terse ut meaningful about Indonesia is a country that implements the system democracy in the administration of government elections. Where the people can elect their leaders. And this is realized one of them by participating in general elections or what we know as election activities carried out by every citizen, both male and female. Especially the participation of women in general elections to take part in the existing changes.

Meanwhile, CNN Indonesia reported that there was a study that there are millennial groups who will not use their voting rights in the 2019 presidential and vicepresidential elections, which are around the number above $40 \%$. Furthermore, according to the CEO of Jeune \& Raccord Communication, Monica JR at a press conference in the Cikini area, Jakarta, the number of 
millennial voters who feel they don't need to come to polling stations is $65.4 \%$, and $25.3 \%$ because they don't know the schedule for the 2019 presidential and vicepresidential elections. . And the remaining 9.3\% for reasons that are not so significant. On the other hand, the impact of globalization in the form of digital developments, especially the existence of social media, causes everyone to be able to access information faster and can be used as a political reference for citizens to know things related to politics, for example, social media, Instagram, Facebook, Twitter. , etc.

And among many other social media, researchers are interested in studying social media Instagram as an educational medium that has a close relationship with Generation $\mathrm{Z}$ and this is because it is based on compass data quoted from NapoleonCat's research. Com shows that the most Instagram social media users are seen from range age and sex differences give us the information that the number of social media users Instagram more women ie 50.8 percent when compared with the number of social media users Instagram men namely 49.2 percent. Meanwhile, when viewed from the age range, most users of Instagram social media are aged 18-36 years. And this group is a group of millennials based on the theory of generational differences from Bencsik, et al in Putra, S (2016) [5] classifying generation $\mathrm{Z}$, known as the millennial generation. Millennials are people born from 19801995.

Nasrullah, R (2020) [6 ] in his book entitled Social Media (Perspective of Communication, Culture, and Sociotechnology) stated that based on his simple survey about student behavior and their dependence on technology and its devices, it shows the fact that students cannot be separated from technology devices. , such as mobile phones ( smartphones/mobile phones ). Therefore, the use of social media as one of the media for political education in an effort to increase political literacy of the younger generation, especially college students. And Instagram social media is not only accessed by young people, but also by older people. All people enjoy digital media as a place to access everything, especially generation $\mathrm{z}$ to increase their political literacy.

Political education that aims to build political awareness of citizens, especially for women, can be built through general education. Which of course is passed or experienced by the educated as a group of people who get more intense knowledge about political education in schools. And of course also have more critical thinking related to a certain condition, situation, or situation. Because here political education using social media Instagram as a tool will see how the perspective of women, especially female students as an educated group.

\section{THEORETICAL REVIEW}

\subsection{Definition of Social Media}

The terminology of social media according to Nasrullah, R (2020) in his book entitled Social Media (Perspective of Communication, Culture, and Sociotechnology) gives an understanding of social media by dividing one by one from the two words, media is defined as a communication tool (Laughey: 2007 McQuail: 2003). Media is a word that always has a meaning related to change and technology [ 6]. Meanwhile, Meyrowitz (1999) in Nasrullah, R (2020) gives the meaning of media as the same meaning as a medium, therefore he gives the meaning of medium into three, first, medium as a channel, whether used for channels that carry messages or in real examples is radio sound. Second, the medium is a language, meaning that the media has something unique that can represent an expression or contain a message. Third, the medium as an environment, means that the media cannot be seen in the text alone, but must also be seen in terms of the context itself [5].

Meanwhile, social according to Durkheim in Nasrullah, R (2020) social refers to the social reality (The Social As Social Facts ) that each individual takes actions that contribute to society. The definition of social is also put forward by Weber, he defines the word social simply as referring to social relations [6]. Finally, according to Tonnies, social refers to the word "community" (Community) which refers to the awareness of members of that community, they have each other and the affirmation of this condition is a togetherness that is dependent on each other. When the two words become one unified word, then social media has an understanding based on social theories developed by Durkheim, Weber, and Tonnies is social media seen from the development of how individuals relate to media devices. Nasrullah, R (2020) also explains how the relationship between existing social theories also applies to social meanings on the internet and describes it in the table below:

Table 1. Social Theory Applications on The Internet

\begin{tabular}{|l|l|l|l|}
\hline No. & Approach & $\begin{array}{l}\text { Social } \\
\text { Theory }\end{array}$ & $\begin{array}{l}\text { Social } \\
\text { Meaning on } \\
\text { the Internet }\end{array}$ \\
\hline 1. & $\begin{array}{l}\text { Structural } \\
\text { Theory }\end{array}$ & $\begin{array}{l}\text { Emilie } \\
\text { Durkheim: } \\
\text { Social facts } \\
\text { are fixed and } \\
\text { objective } \\
\text { social } \\
\text { structures } \\
\text { from the } \\
\text { constant } \\
\text { conditions of } \\
\text { social habits. }\end{array}$ & $\begin{array}{l}\text { All } \\
\text { computers, } \\
\text { programs, } \\
\text { and devices } \\
\text { are social } \\
\text { because } \\
\text { computers } \\
\text { are } \\
\text { structures } \\
\text { that realize } \\
\text { individual } \\
\text { interests, }\end{array}$ \\
\hline
\end{tabular}




\begin{tabular}{|c|c|c|c|}
\hline & & & $\begin{array}{l}\text { understandin } \\
\text { gs, goals, } \\
\text { and interests, } \\
\text { all of which } \\
\text { are functions } \\
\text { of society an } \\
\text { d the result } \\
\text { of social } \\
\text { behavior. }\end{array}$ \\
\hline 2. & $\begin{array}{l}\text { Social } \\
\text { Action } \\
\text { Theory }\end{array}$ & $\begin{array}{l}\text { Max Weber: } \\
\text { Social } \\
\text { behavior is } \\
\text { the } \\
\text { reciprocal of } \\
\text { symbolic } \\
\text { interaction }\end{array}$ & $\begin{array}{l}\text { The } \\
\text { platform is } w \\
w w \text { that } \\
\text { allows } \\
\text { communicati } \\
\text { on to occur } \\
\text { in different } \\
\text { space-times } \\
\text { which are } \\
\text { included in } \\
\text { social }\end{array}$ \\
\hline 3. & $\begin{array}{l}\text { Social } \\
\text { Cooperation } \\
\text { Theory }\end{array}$ & $\begin{array}{l}\text { Ferdinand } \\
\text { Tonnies: } \\
\text { Community } \\
\text { is a social } \\
\text { system } \\
\text { based on a } \\
\text { sense of } \\
\text { commonality } \\
\text { (ownership } \\
\text { ), mutual } \\
\text { need, and } \\
\text { values. }\end{array}$ & $\begin{array}{l}\text { Social } \\
\text { Meaning is } \\
\text { where } \\
\text { the Web } \\
\text { Platform all } \\
\text { ows people } \\
\text { to form } \\
\text { social } \\
\text { networks } \\
\text { (Social } \\
\text { Networking), } \\
\text { bringing } \\
\text { individuals } \\
\text { together and } \\
\text { mediating } \\
\text { virtual } \\
\text { feelings of } \\
\text { togetherness. }\end{array}$ \\
\hline
\end{tabular}

The opinions of other experts regarding social media originating from various research literature according to Fuchs (2014) in Nasrullah, R (2020) are as follows:

1) According to Mandibergh (2012), social media is a medium that facilitates collaboration between users who produce content ( User-Generated Content ).

2) According to Shirky (2008) social media and social software are tools to increase the ability of users to share (to share) cooperate among users and take collective action, all of which are outside the institutional and organizational framework.

3) Boyd (2009) tries to provide an understanding of the meaning of social media as a collection of software that allows individuals and communities to gather, share, communicate, and in certain cases collaborate or play with each other.

4) Finally, Meike and Young (2012), describe the understanding of social media as a convergence between personal communication in the sense of sharing between individuals ( To Be Shared One-To-
One ) and social media is public media to share with anyone without anyone. individual specificity [6].

in the opinion of the experts above we can conclude that social media is software that becomes a forum or channel for everyone to communicate, collaborate (community), interact, and share information with others.

\subsection{The Nature of Political Education}

Political education, better known in English as Political Education, or Political Socialization is an effort carried out by a country with the aim of forming good citizens and in accordance with the aspirations of the nation. At first political education linguistically consisted of two words, first Educare which means training, and secondly political related to politics. Political education is an effort to form good and responsible citizens as expected by the state to the citizens themselves.

Political education according to Affandi, I (2017)[7] is education carried out with the aim or intent so that citizens or the people of the community know and are able to carry out their rights and obligations in every political activity. $\mathrm{P}$ there is essentially political education is indeed a form of a step in transferring knowledge about the value and measures aimed at the shaping of citizens to know their rights and his obligations well and is able to execute consistently.

Meanwhile, Aflian (1981) defines political education as a conscious and planned effort in order to change the political socialization process of the community so that they understand, understand, and apply the political values of the ideal political system to be achieved. And lastly, the definition of a political education by Brohnhill and Smart (in Affandi, 2017:14) [7] explained that political education is an attempt to try to provide a new political experience by slightly leaving the status quo even though political education is a process of indoctrination.

\subsection{Generational Difference Theory}

Putra, S (2016) explained in his journal entitled The Theory of Generational Differences which divides generations that develop from time to time [5]. He began by explaining how the meaning of generation from several experts including according to Kupperschmidt's (2000) stated generation as a group of individuals who identify their group based on the similarity of the year of birth, age, location, and events in the life of the group of individuals that have a significant influence in the growth phase they.

Howe \& Strauss $(1991,2000)$ divide the generation time of birth and the similarity of historical events. Ryder (1965) states that generation is the aggregate of a group of individuals who experience the same events in the same period of time. The conclusion from the meaning of generation is a group formed because of the similarity of several factors and have the same phase of 
life change and experience the same historical phase. In the theory conveyed by Putra, S (2016) there are groupings of generational differences based on the research of Bencsik, Csikos, and Juhez (2016), namely:

Table 2 Generation Differences

\begin{tabular}{|l|l|}
\hline Year of Birth & Generation Name \\
\hline $1925-1946$ & Veteran Generation \\
\hline $1946-1960$ & Baby Boom Generation \\
\hline $1960-1980$ & X Generation \\
\hline $1980-1995$ & Y Generation \\
\hline $\mathbf{1 9 9 5 - 2 0 1 0}$ & Z Generation \\
\hline $2010+$ & Alfa Generation \\
\hline
\end{tabular}

Source: The Theoretical Review: Generation

Difference Theory, Putra, S (2016)

The existing generation has different characteristics of different characters. For example, generation $\mathrm{X}$ is a generation born in the early years of the development of technology and information such as the use of PCs ( Personal Computers ), video games, cable tv, and the internet. And have the ability to adapt, able to accept changes well. and they have an independent and loyal character, and prioritize the image, fame, and money of a hard worker, and calculate the contribution that changes have made to their work (Jurkiewicz, 2000 in Putra S (2016)).

Generation $\mathrm{Y}$ is known as the millennial generation or millennials. This generation group uses technology a lot, while the $\mathrm{z}$ generation has a character that is not too far from the $\mathrm{X}$ generation and $\mathrm{Y}$ generation, where the $\mathrm{Z}$ generation has the ability to apply all activities at one time (Multi Tasking) such as they are able to run social media using cellphones, browsing using PC, and listen to music using a Headset.

\section{METHODS}

Kirk \& Miller (1986) in Moleong (2009) provides a limitation on the meaning that qualitative research comes from a qualitative observation, then debated by observers with quantitative observations that follow the measurement of the level of a certain indicator [8]. Another definition of qualitative research is also conveyed by Denzyme and Lincoln (1987) in Moleong (2009) that qualitative research is research that uses a natural setting (naturalism), which aims to interpret a phenomenon that has occurred and is carried out in a way or way that involves various existing methods. So, in simple terms the understanding of qualitative research put forward by some of the experts above illustrates that qualitative research is research that seeks to interpret, describe, or describe a symptom or situation as it should naturally.

While the method used is phenomenological research methodology. Phenomenological research methodology is a qualitative type of research that tries to explore phenomena or events that need to be studied and occur around us. Meanwhile, according to Meleong, J (2009) tries to provide a definition of the phenomenological method as a form of a person's view of thinking that focuses on the phenomenal or subjective life experience of a person from the human himself and the interpretation of the world or he also simply defines it as a conscious effort that carried out by people/researchers in terms of understanding or studying the meaning of events and their relationships with someone who is in a special condition. And based on the previous explanation, the researcher used a qualitative type of research with a phenomenological methodology which is expected to be able to provide an overview of the Perceptions of Students and Students on the Use of Instagram as a Political Education Tool for Generation Z.

The location or point of this research will be carried out at the Indonesian of Education University, namely the FPIPS Campus (Faculty of Education). Social Science Education) especially students of the S-1 Civic Education Study Program. The time of the research was carried out from 6 to 25 September 2021. The sampling technique was purpose sampling, 20 students from 2 classes totaling 94 and 2 educators from the FPIPS Campus (Faculty of Social Sciences Education), especially students of the S Study Program. -1 Citizenship Education. Data Collection Techniques, Interviews, Documentation Studies, Literature Studies, and Data Validity Tests. Meanwhile, data analysis was carried out through three stages, namely, data collection, data validation, organizing data, presenting data, and interpreting the meaning of the findings, as well as validating the accuracy of the findings.

\section{FINDING AND DISCUSION}

\subsection{Finding}

In the research process, it was found that the facts and perspectives of students and university students on the use of social media (Instagram) as a medium of political education for generation $\mathrm{Z}$ have a good response. they agree that political education on the use of social media (Instagram) as political education for generation $\mathrm{Z}$ is so that they as part of that generation have better political knowledge. and have expertise in processing existing information for their benefit. And from the literature study, it is illustrated that political education carried out in Generation Z, especially for female students, turns out to be able to provide a new perception of politics. Another discussion was about the fact that social media greatly contributes to increasing literacy, but political parties have not been able to optimize it in playing their role as one of the institutions mandated by law to conduct political education. And lastly, from several literature studies that were reviewed regarding several social media that discuss social media can increase generation Z's political literacy. 


\subsection{Discussion}

The role of social media in the political education process at this time is very much felt from the discussion in the theoretical study section above, the existence of social media has become an inseparable part of an individual. Kholisoh, $\mathrm{M}$ et al explained clearly how the contribution of social media, especially to the process of implementing democracy in Indonesia. Where in his journal there is an explanation of the function of social media as a forum for the transformation of values, information, and so on which of course are used by people's daily activities. And that is no exception the political life of course. And Kholisoh, $\mathrm{M}$ et al also explained the second point, namely, the use of social media that is able to contribute, both negatively and positively to the implementation of democracy.

Handoyo, E \& Lestari, P (2017) in his book entitled Political Education describes the position of social media in political education [9]. According to him, there are two models of media used in political education, namely direct media and indirect media. First, direct media is a place or space where the community can be directly involved to be critical and autonomous in the educational processes that are carried out. The media he means include, namely, media in the form of discussions, training, workshops, open debates, all of which he directs to educational materials. Usually, the advantages of using direct media are that they are more effective and successful in achieving educational goals or objectives because these media are usually carried out for a limited number and limited groups. While the weakness is that the media cannot reach its goals quickly in a mass size.

Second, indirect media are media where citizens are not directly involved in the educational process. Indirect media are usually used in educational processes that are carried out en masse with the aim of raising citizens' awareness or providing important information to them about certain public content that must be considered together. The media is not intended to build certain skills or expertise of citizens but is limited to raising awareness or providing information. This indirect media is used to disseminate information en masse, for example, making banners, leaflets, leaflets, newsletters, placing advertisements in mass media, disseminating information via the internet, and so on (Handoyo, E \& Lestari, P, 2017: 133) [9]. And political education can also be done using indirect media, namely the use of social media that uses the internet as an Inter User Connector and one of them is Instagram social media as a contemporary communication. Furthermore, Nasrullah, R (2020: 174) [6], explains the Comparison Table Public Relations Traditional and Public Relations in Social Media [6].

Jordan (1999; 115) in Nasrullah, R (2020: 129) states that a political issue can be created by anyone and discussed as a topic of debate that is followed by anyone. Social media gives users a kind of power to express their aspirations. In fact, if high-ranking political parties or state officials have social media accounts, those aspirations or comments can be directly channeled. This condition shows that the power of social media can change traditional patterns in the digital realm of democratization.

This is as stated by Ittefaq, Alvi, \& Ahmad (2019) The Use of Social Media on Political Participation Among University Students: An Analysis of Survey Results From Rural Pakistan which examines how online political activities impact political efficacy and real-life political participation. among university students in rural Pakistan [10]. And the majority of students use social media for political awareness and information. Political efficacy is significantly based on online political participation. In addition, social media has become a vital platform for netizens to participate in real-life political activities. In conclusion, the research findings show that online political activity is highly correlated with political awareness and offline political participation.

In rural areas of Pakistan, young people are very active on social media. Parmelee \& Roman, N InstaPoliticos: Motivations for Following Political Leaders on Instagram (2019) The survey results presented here show that Instagram has the potential to be a useful political tool if leaders use it in ways that address followers' motives [11]. Respondents indicated that their primary motives for following political leaders on Instagram are for information and guidance. This finding suggests that many followers are receptive to having political Instagram posts guide their voting decisions and political views. Respondents also consider Instagram to be a key news source to stay current on issues and candidates. Respondents' strong informationseeking and guidance motives suggest that political leaders would be wise to be more active on Instagram and focus on providing a steady stream of political news, opinions, personal interests, and other information. Saputra, A Survey of Social Media Use Among Padang City Students Using Uses And Gratifications Theory (2019) From the results of his research, it can be concluded that most of the respondents (students) are active users of social media [12]. And social media becomes the daily life of students. The duration of the use of social media by student groups is 1-6 hours per day. The types of platforms that are most in-demand by students in the City of Padang are WhatsApp (95.96\%), Instagram (90.91\%), and Youtube (73.74\%), and so on.

The last research by Rosadi, et al (2020) The results show that political messages on social media have a significant influence on increasing the political literacy of the millennial generation with an influence level of $77.5 \%$ [13]. The use of social media as an alternative medium in delivering political messages can be used as a means of political education for the community. Thus, the role of social media in Instagram as a forum for 
political education is very important as one of the means used in conveying political messages that contain knowledge, orientation, and values that shape citizens' insights, especially about various problems, institutions, and political leadership at the local, regional, national and international levels. And can foster political awareness of Generation Z.

\section{CONCLUSION}

The perspective of students and college students towards the use of social media (Instagram) as a medium of political education for generation $\mathrm{Z}$ is to have a good response. they agree that political education on the use of social media (Instagram) as political education for generation $\mathrm{Z}$ is so that they as part of that generation have better political knowledge. and have the skills to process the information for their benefit. And from the literature study, it is illustrated that political education carried out in generation $\mathrm{z}$, especially for female students, turns out to be able to give them a new perception of politics. Another discussion was about the fact that social media greatly contributes to increasing literacy, but political parties have not been able to optimize it in playing their role as one of the institutions mandated by law to conduct political education. And lastly, there are several processes of increasing generation Z's political literacy with the existence of social media.

\section{AUTHORS CONTRIBUTIONS}

The author conducts drafting, writing, and discussing the results of research in making this article, and providing guidance with other authors.

\section{ACKNOWLEDGMENTS}

Thank you Allah SWT, parents, and supervisors for writing this journal.

\section{REFERENCES}

[1] S.L. Wahyuningrum, et al, Women and Politics, Vol.1 No.2, Depok: University of Indonesia, 2011. pp. 95-178.

[2] A.P. Budiarti, et al, Women and Politics . Vol.1 No.2, Depok: University of Indonesia, 2011, pp. 95-178.

[3] Law of the Republic of Indonesia Number 7 Year Concerning General Elections.

[4] Kurniawan, N, Women's Representation in the House of Representatives after the Constitutional Court Decision Number 22-24/PUU-VI/2008. Constitutional Journal. Vol. XI, 2014, pp. 714736
[5]Y.S.Putra, Theoretical Review : Generational Difference Theory. Vol. 9. No. 18, Salatiga: STIE Salatiga, 2016, pp. 123-134.

[6] R. Nasrullah, Social Media: (Perspective of Communication, Culture, and Sociotechnology). Bandung: PT Pemuda Rosdakarya, 2020.

[7] I. Affandi, Political Education Book Review by Robert Brownhill and Patricia Smart. Bandung: Main Kencana, 2014.

[8] L.Moleong, Qualitative Research Methodology. Bandung: PT Pemuda Rosdakarya, 2020.

[9] E. Handoyo, \& P. Lestari, Political Education. Yogyakarta: Publisher of the Tree of Light, 2017.

[10] T. Ahmad, A. Alvi, \& M. Ittefaq, The Use of Social Media on Political Participation Among University Students: An Analysis of Survey Results From Rural Pakistan, 2019 SAGEOpen, 9 (3). https://doi.org/10.1177/2158244019864484

[11] J.H. Parmelee, \& N. Roman, Insta-Politicos: Motivations for Following Political Leaders on Instagram. Social Media + Society, 5 (2), 2019 205630511983766. https://doi.org/10.1177/2056305119837662

[12] A. Saputra, Survey of Social Media Use Among Padang City Students Using Uses and Gratifications Theory. Read Journal of Documentation and Information, 40 (2), A, 2019, pp: 207. https://doi.org/10.14203/j.baca.v40i2.476

[13] B. Rosadi, C. Darmawan, \& L. Anggraeni, the Influence of Political Message on Social Media for Increasing the Political Literacy of Millennials, Journal of Civicus, 20 (1), L, 2020, pp:. 26-30. 